\title{
ABO blood groups, secretor status, salivary protein, and serum and salivary immunoglobulin concentrations
}

\author{
J. G. WAISSBLUTH AND M. J. S. LANGMAN \\ From the University Department of Medicine, General Hospital, Nottingham
}

SUMMARY Serum and salivary protein and immunoglobulin concentrations have been measured in people of different ABO blood groups and secretor status. The results have confirmed that salivary protein concentrations vary markedly according to an individual's blood group tending to be particularly high in people of group A, but have failed to show any parallel variation in serum protein concentrations. No clear differences were detected in immunoglobulin concentrations, although salivary IgA concentrations tended to be slightly higher in $\mathrm{ABH}$ secretors than in non-secretors.

Liability to a number of gastrointestinal diseases including salivary tumours (Cameron, 1958; Osborne and de George, 1962), gastric cancer (Aird, Bentall, and Roberts, 1953), pernicious anaemia (Roberts, 1957), and duodenal ulcer (Aird, Bentall, Mehigan, and Roberts, 1954) has been found to be associated with the $\mathrm{ABO}$ blood groups. The reasons for these associations are not clearly understood, but they do not seem to be directly related to simple protective actions of the blood group substances in the secretions (McConnell, 1966; Langman, 1970).

Additional physiological associations have recently been detected between salivary protein concentrations, ABO blood groups, and secretor status (Hope, Mayo, and Boettcher, 1968) and between serum immunoglobulin concentrations and secretor status (Grundbacher and Shreffler, 1970). It is also known that the immunoglobulin content of the intestinal secretions, such as saliva, differs from that of serum in containing an unusually high concentration of IgA (Chodirker and Tomasi, 1963; Tomasi, Tan, Solomon, and Prendergast, 1965). Secretory immunoglobulins almost certainly fulfil a protective role in the gut and it therefore seemed possible that the known associations between the ABO blood groups and upper gastrointestinal disease could be more directly explained by associations between immunoglobulin secretion and the ABO blood groups. We have, therefore, sought to confirm that salivary protein concentrations differ according to a person's ABO blood group and secretor status and have extended these observations to include measureReceived for publication 27 May 1971. ments of serum and salivary immunoglobulin concentrations. All salivary determinations were made using whole mixed saliva because variation in total protein concentration with blood group was detected in such samples and because mixed secretion, rather than an individual pure glandular secretion, is a better measure of the intraluminal environment.

\section{Method}

Samples of blood and saliva were collected from healthy individuals and from hospital patients with haemorrhoids, varicose veins, or inguinal herniae but with no other illness. Fifty $\mathrm{ml}$ of whole mixed saliva was collected without stimulation, except by chewing an inert plastic material (Parafilm), in tubes containing $0.5 \mathrm{ml}$ of $1 \%$ sodium azide as a preservative. The larger part $(40 \mathrm{ml})$ was centrifuged at $30,000 \mathrm{rpm}$ for one hour and the clear supernatant was concentrated 10 to 20 times by negative pressure dialysis using a barbitone buffer at $p \mathrm{H} 8 \cdot 6$ at $4-6^{\circ} \mathrm{C}$. This $40 \mathrm{ml}$ was used to measure immunoglobulin and total protein concentrations, whilst the remainder was boiled for 10 minutes and stored at $-10^{\circ} \mathrm{C}$ before the secretor status was determined. Samples of clotted venous blood were obtained at the same time as the salivary samples and used to determine ABO blood groups and total protein and immunoglobulin concentrations.

ABO blood groups were determined by standard agglutination techniques and secretor status by an agglutination inhibition technique using Ulex europaeus (Boyd and Shapleigh, 1954). Total protein 
concentrations of serum and saliva were measured spectrometrically by the Folinphenol technique (Lowry, Rosebrough, Farr, and Randall, 1951) using suitable dilutions of a commercially available standard serum. The concentrations of $\operatorname{IgA}, \operatorname{IgM}$, and IgG in serum and of IgA and IgG in saliva were measured by the radial immunodiffusion technique (Mancini, Carbonara, and Heremans, 1965) using commercially available immunodiffusion plates and standard antisera, which were suitably diluted during measurements. Since IgA is present in the secretions predominantly in a 115 form-which diffuses more slowly than the 75 non-secretory variety-results were corrected by multiplication by 1.4 (Hobbs, 1970). During preliminary experiments it was found that when small amounts of serum or concentrated saliva were added to mixed saliva before centrifugation and concentration the expected additional amounts of immunoglobulin could be detected at the completion of the concentration procedure. IgM could not, however, be detected in the mixed saliva except when deliberately added or when the saliva was contaminated with blood; all such contaminated samples were discarded. When duplicate salivary samples were collected at different times from the same individual it was found that the amounts of $\operatorname{IgA}$ and IgG detected varied by $2-8 \%$.

\section{Results}

Table I shows the serum and salivary protein concentrations found in people of different ABO blood groups. Mean salivary total protein concentrations were considerably lower in individuals of group $\mathbf{O}$ than in those of the remaining blood groups $(t=4 \cdot 13$, $P<0.001)$. The slight differences detected between mean serum protein concentrations in the same individuals were, however, statistically insignificant and no overall correlation could be detected between serum and salivary protein concentrations $(r=0.05$, $P>0 \cdot 25$ ). Salivary protein concentrations were found to increase with age and to be markedly greater in men than women. There was, however, no substantial difference in the mean ages of individuals of each of the blood groups, and salivary protein concentrations were consistently higher in men and women of group A than in those of group $O$ (Table I), the number of people of groups $B$ and $A B$ being too few to allow men and women to be considered separately.

The results of serum and salivary immunoglobulin determinations are shown in Table II. No clear

\begin{tabular}{|c|c|c|c|c|}
\hline & \multicolumn{4}{|c|}{ Blood Group } \\
\hline & $O$ & $A$ & $\boldsymbol{B}$ & $A B$ \\
\hline \multicolumn{5}{|c|}{ Serum immunoglobulin concentration ( $m g \%$ ) } \\
\hline Mean & 243.0 & $241 \cdot 6$ & $230 \cdot 3$ & $210 \cdot 3$ \\
\hline No. & 47 & 40 & 10 & 4 \\
\hline Mean & $1227 \cdot 7$ & 1233.4 & 1392.9 & $1006 \cdot 7$ \\
\hline $\begin{array}{l}\text { No. } \\
\text { IgM }\end{array}$ & 38 & 27 & 7 & 3 \\
\hline Mean & $146 \cdot 8$ & $130 \cdot 2$ & $153 \cdot 8$ & $112 \cdot 5$ \\
\hline No. & 47 & 40 & 10 & 4 \\
\hline \multicolumn{5}{|c|}{ Salivary immunoglobulin concentration ( $m g \%$ ) } \\
\hline IgA & & & & \\
\hline Mean & 0.91 & 1.00 & $0 \cdot 85$ & 0.77 \\
\hline SEM & $0 \cdot 10$ & $0 \cdot 17$ & 0.35 & - \\
\hline \multicolumn{5}{|l|}{ IgG } \\
\hline Mean & 0.65 & 0.56 & 0.84 & $0 \cdot 13$ \\
\hline SEM & 0.08 & 0.06 & 0.35 & - \\
\hline No. & 26 & 17 & 4 & 1 \\
\hline
\end{tabular}

Table II Serum and salivary immunoglobulin concentrations in men and women of different $A B O$ blood groups

differences were detected in the serum and salivary concentrations of immunoglobulins in people of the different ABO blood groups. Salivary samples, as expected, contained a higher proportion of IgA relative to IgG than would have been expected from

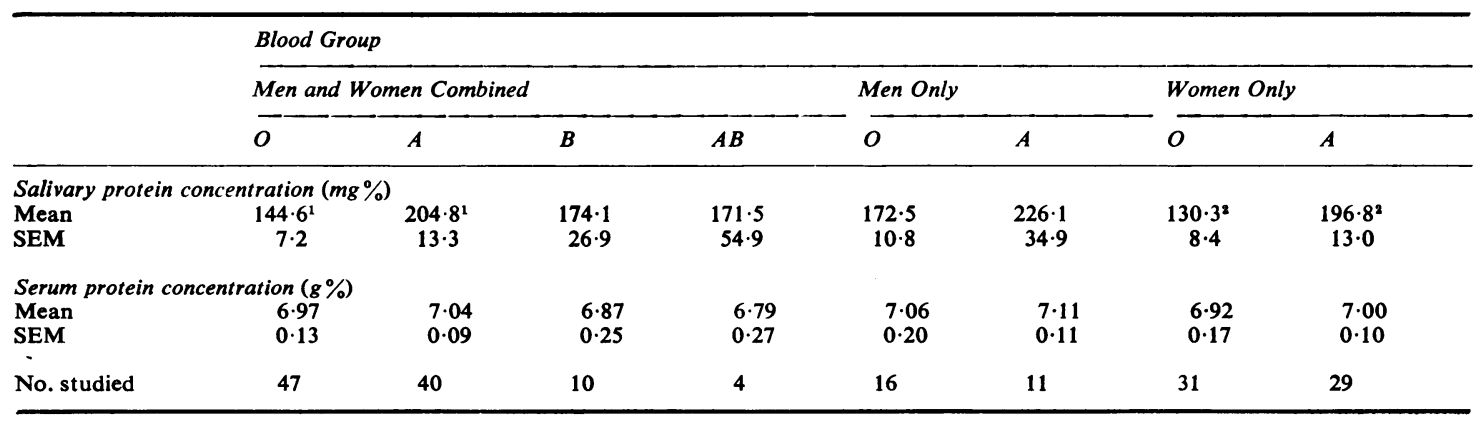

Table I Serum and salivary protein concentrations in individuals of different ABO blood groups

'Statistically significant: $\mathrm{t}=4 \cdot 1, \mathrm{P}<0.001$.

${ }^{2}$ Statistically significant: $t=4 \cdot 4, P<0.001$. 
their respective serum concentrations. This result is in keeping with the presence of a specific salivary transport system for $\operatorname{IgA}$ but there were no significant differences in the salivary concentrations of IgA in individuals of the different ABO blood groups.

The results of determinations of serum and salivary immunoglobulin concentrations in ABH secretors and non-secretors are shown in Table III. Though serum concentrations of the three immunoglobulins measured were consistently lower in non-secretors than in secretors, the differences were small and none were statistically significant. Comparisons between serum immunoglobulin concentrations were made after conversion of all individual results to logarithms to compensate for the skew distribution of the figures. Salivary immunoglobulin and total protein concentrations were also slightly lower in non-secretors than in secretors but none of the differences, except that for $\operatorname{IgA}(t=2 \cdot 1, P=0.05)$, were statistically significant.

\begin{tabular}{|c|c|c|}
\hline & Secretors & Non-secretor \\
\hline \multicolumn{3}{|c|}{$\begin{array}{l}\text { Serum immunoglobulin concentration ( } m g \% \text { ) } \\
\text { IgA }\end{array}$} \\
\hline $\begin{array}{l}\text { Mean } \\
\text { IgG }\end{array}$ & 242.9 & $237 \cdot 7$ \\
\hline $\begin{array}{l}\text { Mean } \\
\text { IgM }\end{array}$ & $1234 \cdot 3$ & 1149.9 \\
\hline $\begin{array}{l}\text { Mean } \\
\text { No. }\end{array}$ & $\begin{array}{c}166 \cdot 6 \\
41\end{array}$ & $\begin{array}{c}151 \cdot 9 \\
15\end{array}$ \\
\hline \multicolumn{3}{|c|}{$\begin{array}{l}\text { Salivary immunoglobulin concentration }(m g \%) \\
\text { IgA }\end{array}$} \\
\hline $\begin{array}{l}\text { Mean } \\
\text { SEM } \\
\text { IgG }\end{array}$ & $\begin{array}{l}1 \cdot 02^{1} \\
0 \cdot 10\end{array}$ & $\begin{array}{l}0.65^{1} \\
0.07\end{array}$ \\
\hline $\begin{array}{l}\text { Mean } \\
\text { SEM } \\
\text { No. }\end{array}$ & $\begin{array}{l}0.66 \\
0.07 \\
36\end{array}$ & $\begin{array}{l}0 \cdot 54 \\
0 \cdot 10 \\
12\end{array}$ \\
\hline $\begin{array}{l}\text { Salivary } \\
\text { Mean } \\
\text { SEM } \\
\text { No. }\end{array}$ & $\begin{array}{l}\%) \\
150 \cdot 6 \\
8 \cdot 6 \\
41\end{array}$ & $\begin{array}{c}140 \cdot 0 \\
12 \cdot 5 \\
15\end{array}$ \\
\hline
\end{tabular}

Table III Salivary protein concentrations and serum and salivary immunoglobulin concentrations in men and women of different secretor status

${ }^{1}$ Statistically significant: $t=2 \cdot 1, P=0.05$.

\section{Discussion}

The results of this investigation have confirmed the earlier finding that individuals of group $A$ have higher salivary protein concentrations than those of group $O$ and, probably, of groups $B$ and $A B$ (Hope et al, 1968). However, no clear differences have been found in serum protein concentrations associated with the ABO blood groups. Salivary protein concentrations were also shown earlier to be greater in people of group $A_{2}$ than in those of group $A_{1}$ and to be greater in $\mathrm{ABH}$ secretors than in non-secretors independently of the ABO blood group. We have not sought to confirm the first of these differences but we have found salivary protein concentrations to be slightly, though not significantly higher in secretors than in non-secretors; the lack of a clear difference is possibly due to the smaller number of nonsecretors studied in the present series.

The marked difference in salivary protein concentrations for the different $\mathrm{ABO}$ blood groups, and the absence of such a difference in serum protein concentrations suggest that the presence of protein in saliva is due, at least in part, to a specific transport mechanism associated with the ABO blood groups, and not to simple diffusion. The molecules of the blood group substance consist of a protein core with a carbohydrate side chain and the ABO and secretor genes, together with those for the Lewis blood groups, determine the characteristics of the sugar moiety (Watkins, 1966). Blood group glycoproteins form such a small proportion of the total protein present in saliva that differences in their amounts could not explain the variation according to $\mathrm{ABO}$ blood group which has been observed.

Though there is known to be a specific secretory system for $\operatorname{IgA}$ we have been unable to detect differences in salivary $\operatorname{Ig} \mathrm{A}$ concentrations in mixed saliva to parallel those differences found in serum protein concentrations. Salivary IgA concentrations were significantly lower in non-secretors than in secretors, but it is difficult to know whether this difference is due to anything more than the expected random variation when a number of independent statistical comparisons are made.

Serum IgG concentrations (but not IgA or IgM) have recently been found to be lower in ABH nonsecretors than in secretors (Grundbacher and Shreffler, 1970) and our results show a similar trend. In addition, our results show a tendency for salivary IgG concentrations to be lower in non-secretors than in secretors; however, this difference was not statistically significant and it seems likely that if there is any variation it-like that detected in serumis likely to be small.

The basis and significance of the genetic variation detected in protein concentrations in salivary secretion is unclear. An association has previously been detected between ABO blood groups, secretor status, and serum and mucosal concentrations of small intestinal alkaline phosphatase (Arfors, Beckman, and Lundin, 1963; Shreffler, 1965; Bamford, Harris, Luffman, Robson, and Cleghorn, 1965; Langman, Constantinopoulos, and Bouchier, 1968). But, whereas salivary protein concentrations tend to be high in people of group A and in secretors, higher enzyme concentrations have been detected in 
those of groups $\mathrm{O}$ and $\mathrm{B}$ and in secretors. This lack of parallelism between the $\mathrm{ABO}$ and secretor associations for intestinal alkaline phosphatase and for salivary protein suggests that the mechanisms behind the two effects differ.

\section{References}

Aird, L., Bentall, H. H., Mehigan, J. A., and Roberts, J. A. F. (1954). The blood groups in relation to peptic ulceration and carcinoma of colon, rectum, breast and bronchus. med. Brit.J., 2, 315-321.

Aird, L., Bentall, H. H., and Roberts, J. A. F. (1953). A relationship between cancer of stomach and the ABO blood groups. Brit. med. J., 1, 799-801.

Arfors, K. E., Beckman, L., and Lundin, L. G. (1963). Further studies on the association between human serum phosphatases and blood groups. Acta genet. (Basel), 13, 366-368.

Bamford, K. F., Harris, H., Luffman, J. E., Robson, E. B., and Cleghorn, T. E. (1965). Serum-alkaline-phosphat ase and the ABO blood groups. Lancet, 1, 530-531.

Boyd, W. C., and Shapleigh, E. (1954), Separation of individuals of any blood group into secretors and nonsecretors by use of a plant agglutinin (lectin). Blood, 9, 1195-1198.

Cameron, J. M. (1958). Blood-groups in tumours of salivary tissue. Lancet, 1, 239-240.

Chodirker, W. B., and Tomasi, T. B. Jr. (1963). Gamma-globulins: quantitative relationships in human serum and nonvascular fluids. Science, 142, 1080-1081.

Grundbacher, F. J., and Shreffler, D. C. (1970). Effects of secretor, blood, and serum groups on isoantibody and immunoglobulin levels. Amer. J. hum. Genet., 22, 194-202.

Hobbs, J. R. (1970). Immune globulins in some diseases. Brit. J. hosp. med., 3, 669-680.

Hope, R. M., Mayo, O., and Boettcher, B. (1968). Protein concentrations of salivas from secretors and nonsecretors. Vox Sang., (Basel), 15, 70-74.

Langman, M. J. S. (1970). ABO blood groups and gastrointestina function. Gut, 11, 796-798.

Langman, M. J. S., Constantinopoulos, A., and Bouchier, I. A. D. (1968). ABO blood groups, secretor status, and intestinal mucosal concentrations of alkaline phosphatase. Nature (Lond.), 217, 863-865.

Lowry, O. H., Rosebrough, N. J., Farr, A. L., and Randall, R. J. (1951). Protein measurement with the Folin phenol reagent. J. biol. Chem., 193, 265-275.

McConnell, R. B. (1966). The Genetics of Gastrointestinal Disorders. Oxford University Press, London.

Mancini, G., Carbonara, A. O., and Heremans, J. F. (1965). Immunochemical quantitation of antigens by single radial immunodiffusion. Immunochemistry, 2, 235-254.

Osborne, R. H., George, F. V. de (1962). The ABO blood groups in parotid and submaxillary gland tumours. Amer.J. hum. Genet., 14, 199-209.

Roberts, J. A. F. (1957). Blood groups and susceptibility to disease: a review. Brit. J. prev Soc. Med., 11, 107-125.

Shreffler, D. C. (1965). Genetic studies of blood group-associated variations in a human serum alkaline phosphatase. Amer. J. hum. Genet., 17, 71-86.

Tomasi, T. B. Jr., Tan, E. M.,Solomon, A., and Prendergast, R. A. (1965). Characteristics of an immune system common to cert ain external secretions. J. exp. Med., 121, 101-124.

Watkins, W. M. (1966). Blood group substances. Science, 152, 172-181. 